\title{
Effect of Shear Wave Velocity of Soil on Behavior of Mid-Rise Reinforced Concrete Frame Structures
}

\author{
Serkan Engin* \\ Kocaeli University, Umuttepe Campus, Engineering Faculty, Civil Engineering Department, İzmit / KOCAELI \\ Tel: 026230332 89, Fax: 026230330 03, \\ serkan.engin@kocaeli.edu.tr \\ *Corresponding Author \\ Recieved: 9 December 2016 \\ Accepted: 5 June 2017 \\ DOI: $10.18466 /$ cbayarfbe.339342
}

\begin{abstract}
The most significant parameter of nonlinear time history analysis is the quality of strong ground motion record which will be used. In this paper, the near-field earthquakes including the forward directivity which have been recorded from two different soil classes were scaled in accordance with the design spectrum of probability of exceedance was $10 \%$. Following this, the nonlinear time history analyses of a typical mid-rise reinforced concrete frame structure were conducted by using the strong ground motion records which were scaled. As a result of the analyses made, the shear force, bending moment and interstory drift ratio curves of structures were acquired for each soil classes. By comparing these curves acquired for different soil classes with each other, the effect of soil characteristics on which the structure will be constructed on the results were discussed. According to this, it has been observed that as the shear wave velocity of soil decreases, internal forces and displacements in the structure increase.
\end{abstract}

Keywords - Time History Analysis, Shear Wave Velocity of Soil, Forward Directivity, Internal Forces of Structure, Interstorey Drift Ratio.

\section{Introduction}

The most reliable method in the analysis which was conducted for the earthquake resistant structure design is accepted as the time history analysis [1]. Although this analysis method is accepted as the most reliable method, the reliability of method is affected from various variables. The most significant parameter of this method is obtaining the convenient earthquake record. These increase the reliability of results which will be obtained from the analyses that the earthquake record to be used in the time history analysis should be convenient for the structure and the area at which the structure will be constructed [2]. In spite of that the execution area of method has spread along with the recent technological developments, it is not still known exactly that the earthquake records to be used in the analysis shall which characteristics [3]. But it was mostly observed that the buildings in the areas up to $20 \mathrm{~km}$ far away (in other words, the near-field) from the source mechanism of earthquake affected from the earthquake more [4]. It was seen that in some cases, the buildings affected from the earthquake more although they were in near-field. It was foreseen that this difference may be resulted from the frequency content of strong ground motion. In the study which was conducted by Metin on this subject, it was determined that the earthquake motion propagation at high velocity from the fault surface fracture to the settlement area caused to high amplitude effect within the direction of fault normal and this effect was identified as the forward directivity effect [5]. In the study which was conducted by Mavroeidis, the forward directivity effect was defined as the seismic propagation of almost all elastic energy in the fault in accordance with the dense period at the starting of earthquake record [6]. Accordingly, it may be said that the forward directivity effect (FD) may be seen in case the strong ground motion propagation is towards the area at which the study is conducted and FD is not seen in case the propagation moves away the study area.

The example velocity-time graphics for the strong ground motion records including and not including FD is given in Figure 1. In this Figure, the light color line indicates the record taken from TCU084-N station of Chi-Chi earthquake which occurred in 1991 and the dark color line indicates CHY101-N station of same earthquake. The station at which CHY101-N record was recorded was in the 
direction of fracture and here, the strong ground motion spread at a higher velocity. The station from which TCU084-N record was taken was contrary to the fracture direction and the strong ground motions spread towards this station at a lower velocity. This propagation at CHY101-N record of strong ground motion is called as FD. There is no FD at TCU084-N record as it spread at a lower velocity.

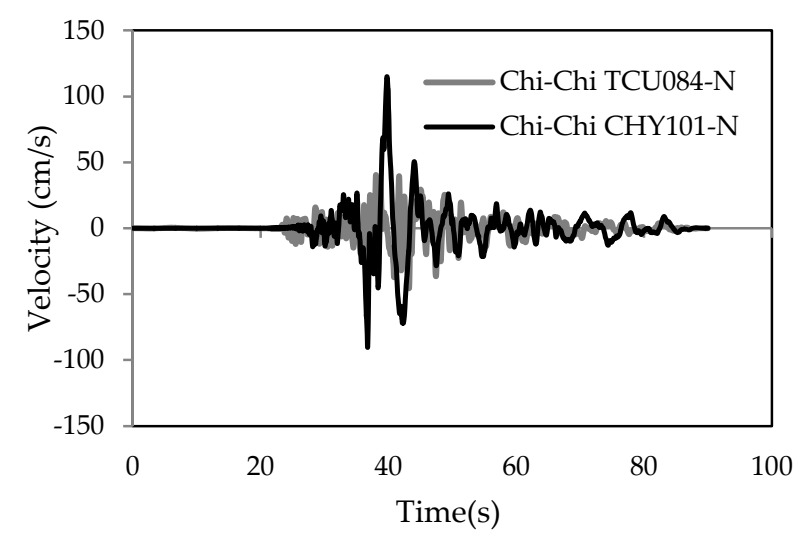

Figure 1. Chi-Chi CHY101-N velocity-time graphic including FD and Chi-Chi TCU084-N velocity-time graphic not including FD

In the study which was conducted by Ventura et all. [7], the effect of strong ground motion including FD on the high storey structures were investigated. At the end of study, it was foreseen that the strong ground motions including FD created higher internal forces at high storey structures. Another parameter which affects the seismic behavior of structure is the characteristics of soil on which the structure will be constructed. According to American Society of Civil Engineers, Minimum Design Loads for Buildings and Other Structures Standard (ASCE) [8], the soils of which average shear wave velocities vary between $180 \mathrm{~m} / \mathrm{s}$ and $360 \mathrm{~m} / \mathrm{s}$ represent the soil class D and the soils of which average shear wave velocities vary between $360 \mathrm{~m} / \mathrm{s}$ and $760 \mathrm{~m} / \mathrm{s}$ represent the soil class C. It is foreseen that the behavior of structures on the soils of which shear wave velocities are different may be also variable. In spite of these foresights, it does not still seem possible to make generalization concerning to which characteristics of strong ground motions will have a what kind of effect on the structures. Therefore, there is still a necessity to make analyses with earthquake records having different characteristics for different structures.

In this paper, it was aimed to investigate the effect of shear wave velocity of soil (soil class) on which the strong ground motion including FD was recorded on the mid-rise reinforced concrete frame structures. Therefore, two different earthquake record groups including forward directivity effect recorded from the soil classes $\mathrm{C}$ and $\mathrm{D}$ in the near-field were recorded. The records in the groups were scaled in accordance with the design spectrum of which the probability of exceedance was $10 \%$ in 50 years. By using these records scaled, the nonlinear time history analyses of the structure selected were conducted. At the end of analyses, the change curves of structure internal forces and displacements in accordance with the floor level were obtained. By comparing the results obtained from two groups, the effect of strong ground motions including forward directivity effect recorded in the near-field on the seismic behavior of soil class were discussed.

\section{Analytical Study}

In this part of study, the acceptances made during the creation of structure model, selection of earthquake records, the analyses made and the data obtained from these analyses are presented.

\subsection{Analytical Model of Structure}

For the study, a typical mid-rise reinforced concrete frame structure was selected. The information concerning to the characteristics of building is given in Table 1 .

Table 1. The characteristics of building used in the study.

\begin{tabular}{|l|c|}
\hline Building Characteristics & Value \\
\hline Compressive Strength of Concrete $\left(f_{c k}\right)$ & $40 \mathrm{MPa}$ \\
\hline Yield Strength of Reinforcement Steel $\left(f_{s y}\right)$ & $420 \mathrm{MPa}$ \\
\hline Building Importance Factor $(I)$ & 1 \\
\hline Structural System Behavior Factor $(R)$ & 8 \\
\hline Effective Ground Acceleration Coeff. $\left(\mathrm{A}_{0}\right)$ & 0.40 \\
\hline Spectrum Characteristic Period & $\begin{array}{c}T_{A}=0.15 \mathrm{~s} \\
T_{B}=0.40 \mathrm{~s}\end{array}$ \\
\hline Height of Storey of Building $\left(h_{f}\right)$ & $3 \mathrm{~m}$ \\
\hline Number of Storey & 5 \\
\hline
\end{tabular}

Accordingly, the compressive strength of concrete was taken as $f_{c k}=40 \mathrm{MPa}$ and yield strength of longitudional and transverse reinforcement steel bar was taken as $f_{y}=420$ MPa. By taking the building importance factor as $I=1$, the structural system behavior factor as $R=8$, the effective ground acceleration coefficient as $A_{o}=0.40$ and the spectrum characteristic period as $T_{A}=0.15, T_{B}=0.40$ ( $\mathrm{Z} 2$ spectrum class), linear dynamic analysis was conducted with the aim of obtaining the vertical load values of columns. In this analysis, the increased load which was obtained by adding $30 \%$ of live loads $(Q)$ taken as 7.50 $\mathrm{kN} / \mathrm{m}^{2}$ to the dead loads taken as $3.00 \mathrm{kN} / \mathrm{m}^{2}$ had an impact on the floorings. In the study, the storey number of structure was taken as 5 , the height of each storey as $h_{f}=3 \mathrm{~m}$, the clearance of structure at both directions as three, the 
distance between the axes as $6 \mathrm{~m}$, the flooring thickness as $0.20 \mathrm{~m}$, the beam sizes at all stories as $b_{w}=0.30 \mathrm{~m}, h_{k}=0.60$ $\mathrm{m}$ and the column dimensions as $b=0.50 \mathrm{~m}, h=0.50 \mathrm{~m}$.

The floor plan of study structure is given in Figure 2 and the reinforced steel bar layout of column and beam sections is given in Figure 3. As a result of linear dynamic analysis which was conducted under these conditions, the axial loads on the vertical elements of building were obtained and first natural vibration periods of building was determined as $T_{x}=0.52 \mathrm{~s}, T_{y}=0.52 \mathrm{~s}$.

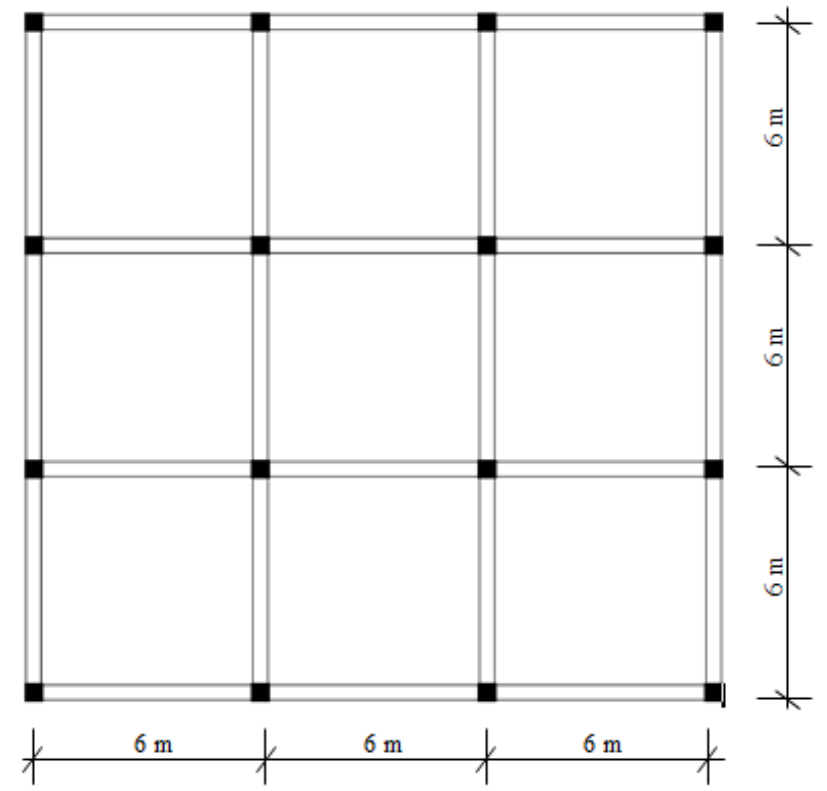

Figure 2. Floor plan of building.

For the concrete behavior, the confined and unconfined Mander concrete model $[9,10]$ was used. The general stress- strain $\left(f_{c}-\varepsilon_{c}\right)$ belonging to the confined and unconfined concrete is given in Figure 4. In this figure, $f_{c o}$ the compressive strength of unconfined concrete, $f_{c c}$ the compressive strength of confined concrete, $\varepsilon_{c o}$ the strain to maximum compressive strength of unconfined concrete (generally 0.002 ), $\varepsilon_{c c}$ the strain to maximum compressive strength of confined concrete and $\varepsilon_{c u}$ ultimate strain in the confined concrete are shown. For the reinforced steel bars in the concrete sections, the behavior model of reinforced steel bar defined in Turkish Earthquake Code 2007 [11] and given in Figure 5 was used.

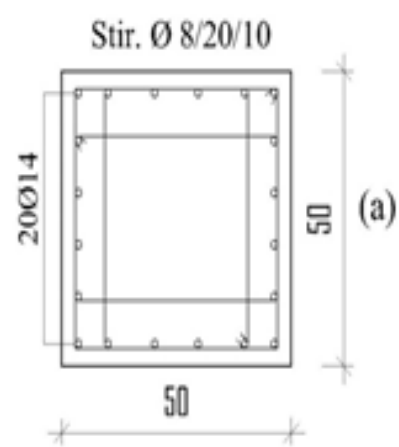

(all dimensions, $\mathrm{cm}$ )

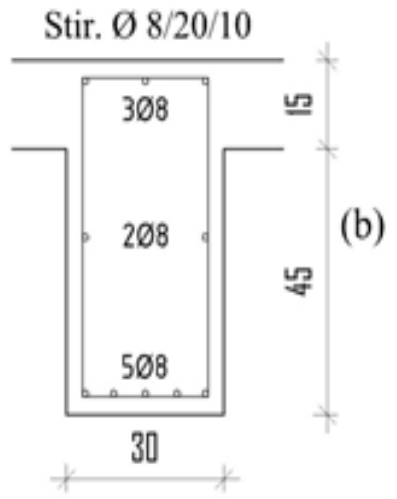

Figure 3. a-) Beam; b-) Column reinforced configuration.

In this model, $f_{s y}$ refers to the yield stress of reinforced steel bar, $\varepsilon_{s y}$ refers to the strain to the yield stress, $f_{s u}$ refers to the rupture stress of reinforced steel bar, $\varepsilon_{s u}$ refers to the unit strain to rupture stress and $\varepsilon_{s h}$ refers to the strain of steel at the start of strain hardening.

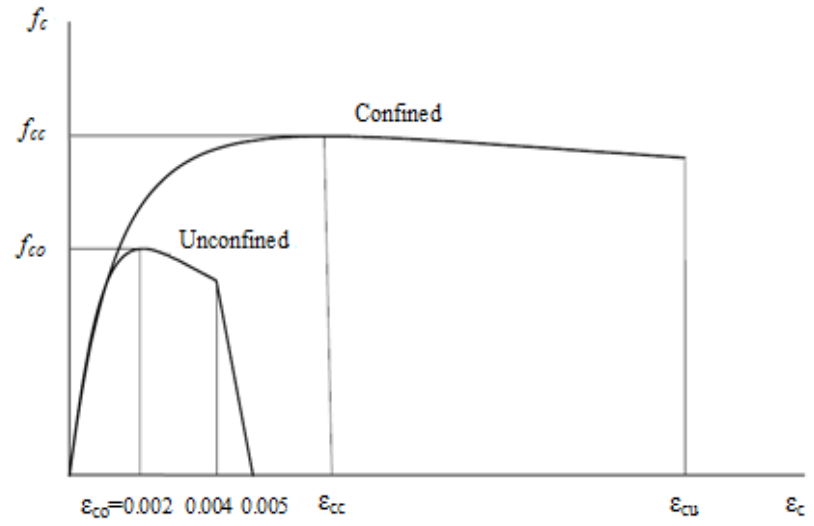

Figure 4. Confined and unconfined Mander Concrete Model.

These variables are given in below Table 2 for the reinforced steel bar which was used in the study. The column and beam elements was defined as the frame elements in the analytical model and the capacity diagrams of each element defined were determined by using the data which were defined with XTRACT [12] cross-section analysis program.

Table 2. The characteristics of reinforced steel bar

\begin{tabular}{|c|c|c|c|c|}
\hline $\boldsymbol{f}_{\text {sy }}(\mathbf{M P a})$ & $\boldsymbol{\varepsilon}_{\text {sy }}$ & $\boldsymbol{\varepsilon}_{\text {sh }}$ & $\boldsymbol{\varepsilon}_{\text {su }}$ & $\boldsymbol{f}_{\text {su }}(\mathbf{M P a})$ \\
\hline 420 & 0.0021 & 0.008 & 0.10 & 550 \\
\hline
\end{tabular}


Celal Bayar University Journal of Science

Volume 13, Issue 3, p 695-705

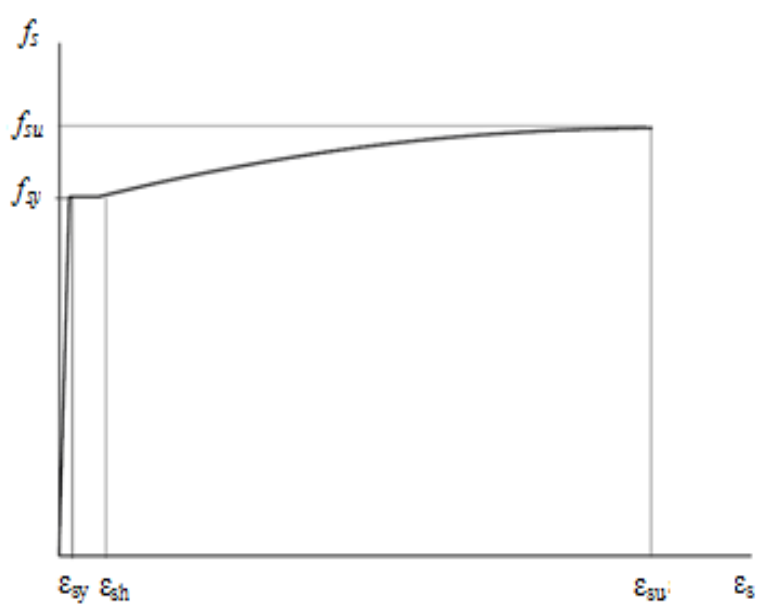

Figure 5. The reinforced steel defined in Turkish Earthquake Code.

The column axial loads which are necessary for crosssection analysis were obtained as a result of linear dynamic analysis. In the beams, axial load was taken as zero in the capacity curve. The yield and ultimate curvature and yield moment values of structure elements were determined by using these data. The structure analytical model given in Figure 5 and Figure 6 was created with all these data in SAP2000NL [13] analysis program.

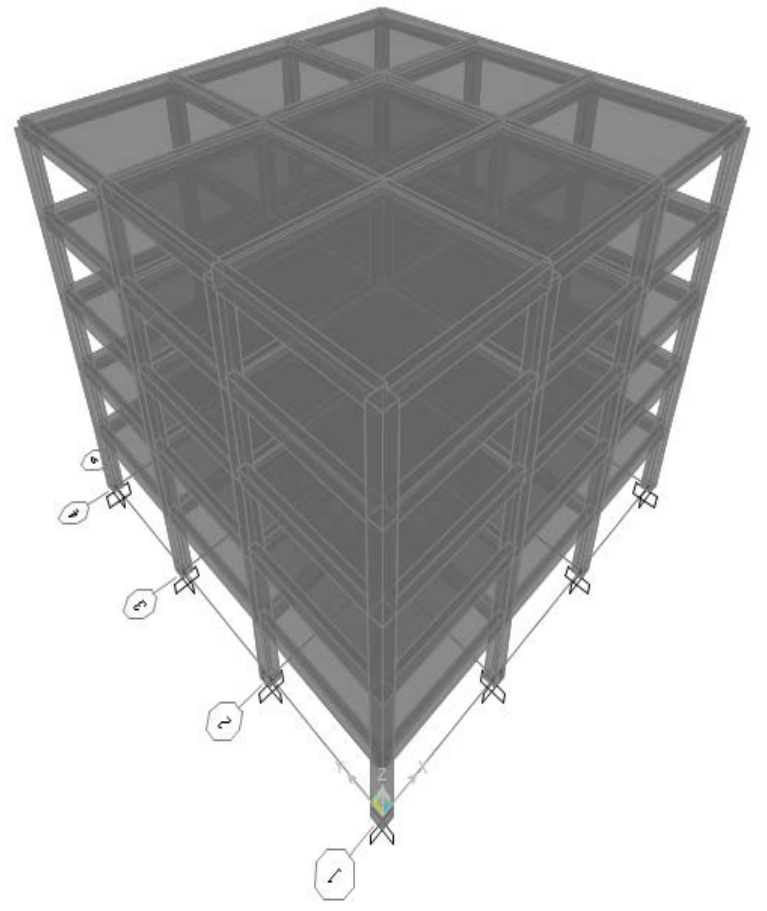

Figure 6. The 3-dimensional view of structure analytical model

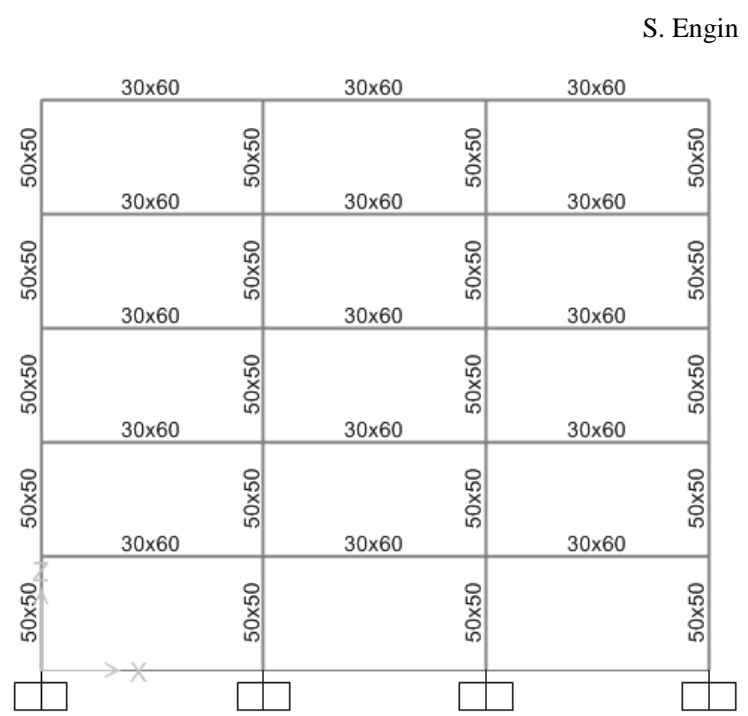

Figure 7. 2-dimensional view and cross-section properties of structure analytical model

\subsection{Selection and Scalling of Earthquake Records}

In accordance with the codes on design $[8,11]$, it is required to scale the ground motions to be used in the time history analysis shall be scaled in conformity with a specific design spectrum. In this part, near-field origin two group earthquake records including FD were selected from two different soil classes for scaling.

Table 3. The records of which Vs $=180-360 \mathrm{~m} / \mathrm{s}$ (group D) and including FD

\begin{tabular}{|c|c|c|c|c|c|c|c|c|}
\hline 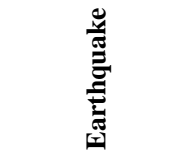 & 芫 & 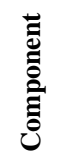 & 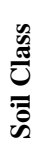 & $\sum^{3}$ & $\underset{\widetilde{a}}{\widehat{\widetilde{E}}}$ & 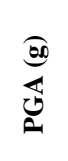 & 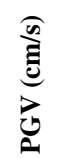 & 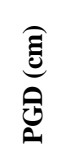 \\
\hline $\begin{array}{l}\text { Düzce } \\
\text { (D-B) }\end{array}$ & Bolu & 90 & D & 7.1 & 12.0 & 0.82 & 62.1 & 13.6 \\
\hline $\begin{array}{l}\text { Northridge (N- } \\
\text { NWPC) }\end{array}$ & & 46 & D & 6.7 & 5.5 & 0.45 & 92.8 & 56.6 \\
\hline $\begin{array}{l}\text { Chi-Chi } \\
\text { (CC-CHY101) }\end{array}$ & CHY101 & $\mathrm{N}$ & D & 7.6 & 10.0 & 0.44 & 115 & 68.8 \\
\hline $\begin{array}{l}\text { Chi-Chi } \\
\text { (CC-TCU101) }\end{array}$ & TCU101 & $\mathrm{E}$ & D & 7.6 & 2.1 & 0.20 & 67.9 & 75.4 \\
\hline $\begin{array}{l}\text { Northridge (N- } \\
\text { CCWLC) }\end{array}$ & WLC & 270 & D & 6.7 & 12.0 & 0.48 & 44.9 & 12.5 \\
\hline $\begin{array}{l}\text { Erzincan } \\
\text { (E-E) }\end{array}$ & Erzincan & EW & D & 6.9 & 4.4 & 0.49 & 64.3 & 22.8 \\
\hline $\begin{array}{l}\text { Imperial Val } \\
\text { (IV-ECD) }\end{array}$ & Cen & 360 & D & 6.5 & 5.1 & 0.48 & 40.8 & 14.0 \\
\hline $\begin{array}{l}\text { Imperial Val } \\
\text { (IV-ECA5) }\end{array}$ & $\begin{array}{l}\text { Centro } \\
\text { A55 }\end{array}$ & 230 & D & 6.5 & 4.0 & 0.38 & 90.5 & 63.1 \\
\hline $\begin{array}{l}\text { Imperial Val } \\
\text { (IV-ECA7) }\end{array}$ & $\begin{array}{l}\text { El Centro } \\
\text { Arr\#7 }\end{array}$ & 230 & D & 6.5 & 0.6 & 0.46 & 109 & 44.7 \\
\hline Düzce & zce & 270 & D & 7.1 & 8.2 & 0.53 & 83.5 & 51.6 \\
\hline
\end{tabular}

In Table 3, the earthquake records including FD of which shear wave velocity of soil $\mathrm{V}_{\mathrm{s}}=180-360 \mathrm{~m} / \mathrm{s}$ (within group D) are given. Peak ground velocity (PGV) values of ground 
motions in this group varied between $40.8 \mathrm{~cm} / \mathrm{s}$ and 115.0 $\mathrm{cm} / \mathrm{s}$. The magnitude of earthquakes which produced the acceleration records given in the group varied between $\mathrm{M}_{\mathrm{w}}=6.5$ and $\mathrm{M}_{\mathrm{w}}=7.6$. Peak ground acceleration (PGA) values of aforementioned records varied between $0.20 \mathrm{~g}$ and 0.82 and their peak ground displacement (PGD) values varied between $12.5 \mathrm{~cm}$ and $75.4 \mathrm{~cm}$. The appearance of acceleration-time series belonging to the earthquake records given in Table 3 are shown in Figure 8.

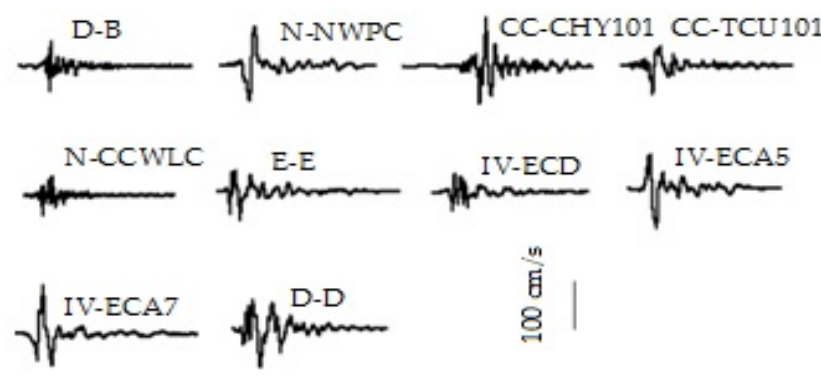

Figure 8. The acceleration-time graphics of records taken from the soil of which Vs $=180-360 \mathrm{~m} / \mathrm{s}$ (group D) and including FD.

Table 4. The records of which Vs $=360-760 \mathrm{~m} / \mathrm{s}$ (group C) and including FD

\begin{tabular}{|c|c|c|c|c|c|c|c|c|}
\hline 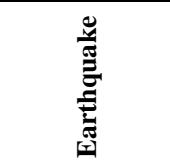 & 总 & 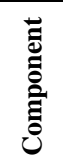 & 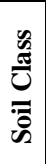 & $\sum^{3}$ & 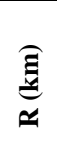 & ஹ્ & 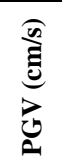 & 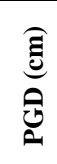 \\
\hline $\begin{array}{l}\text { Northridge } \\
\text { (N-PKC) }\end{array}$ & $\begin{array}{l}\text { Pacoima } \\
\text { Kag. C. }\end{array}$ & 360 & C & 6.7 & 7.3 & 0.43 & 51.5 & 7.2 \\
\hline $\begin{array}{l}\text { Chi-Chi } \\
\text { (CC-TCU68) }\end{array}$ & TCU068 & E & C & 7.6 & 0.3 & 0.57 & 177 & 324 \\
\hline $\begin{array}{l}\text { Loma Prieta } \\
\text { (LP-SWVC) }\end{array}$ & $\begin{array}{l}\text { Saratoga } \\
\text { W Val.C }\end{array}$ & 0 & C & 7.0 & 9.3 & 0.25 & 42.4 & 19.5 \\
\hline $\begin{array}{l}\text { Chi-Chi } \\
\text { (CC-CHY28) }\end{array}$ & СHY028 & $\mathrm{N}$ & C & 7.6 & 3.1 & 0.82 & 67.0 & 23.3 \\
\hline $\begin{array}{l}\text { Loma Prieta } \\
\text { (LP-C) }\end{array}$ & Carrolitas & 090 & C & 7.0 & 3.9 & 0.48 & 45.2 & 11.3 \\
\hline $\begin{array}{l}\text { ImperialVall } \\
\text { (IV-HPO) }\end{array}$ & $\begin{array}{l}\text { Hostville } \\
\text { Post Of }\end{array}$ & 315 & C & 6.5 & 7.7 & 0.22 & 49.8 & 31.9 \\
\hline $\begin{array}{l}\text { Cape Mendo } \\
\text { (CM-P) }\end{array}$ & Petrolia & 0 & C & 7.0 & 6.9 & 0.59 & 48.4 & 21.9 \\
\hline $\begin{array}{l}\text { Cape Mendo } \\
\text { (CM-CM) }\end{array}$ & $\begin{array}{l}\text { Cape } \\
\text { Mendo }\end{array}$ & 0 & C & 7.0 & 6.9 & 1.50 & 127 & 41.0 \\
\hline $\begin{array}{l}\text { Chi-Chi } \\
\text { (CC-TCU103) }\end{array}$ & TCU103 & E & C & 7.6 & 4.0 & 0.13 & 61.9 & 87.6 \\
\hline $\begin{array}{l}\text { Loma Prieta } \\
\text { (LP-SAA) }\end{array}$ & $\begin{array}{l}\text { Saratoga } \\
\text { AlohaA }\end{array}$ & 090 & C & 7.0 & 8.5 & 0.48 & 42.6 & 27.6 \\
\hline
\end{tabular}

In Table 4, the records recorded from the soil of which soil shear wave velocities were $V_{\mathrm{s}}=360-760 \mathrm{~m} / \mathrm{s}$ and which took place in the group $\mathrm{C}$ and including $\mathrm{FD}$ are given. The PGV values of ground motions given in Table 4 varied between $42.4 \mathrm{~cm} / \mathrm{s}$ and $177.0 \mathrm{~cm} / \mathrm{s}$ and the magnitude of earthquakes varied between $M_{w}=6.5$ and $M_{w}=7.6$. The PGA of records varied between $0.13 \mathrm{~g}$ and 1.50 and the PGD values varied between $7.2 \mathrm{~cm}$ and $324.0 \mathrm{~cm}$. The appearance of acceleration-time series of earthquake records given Table 4 are shown in Figure 9.

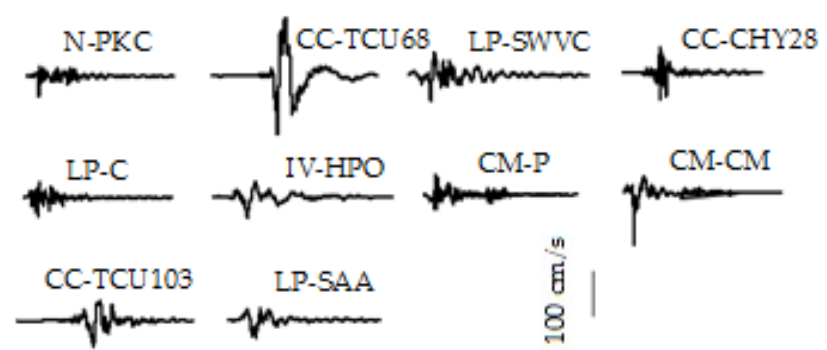

Figure 9. The velocity-time graphics of records taken from the soil of which Vs $=360-760 \mathrm{~m} / \mathrm{sec}$. (group D) and including FD.

In the codes [8,11], seven and above is enough for representation of a target spectrum with the convenient scaling method. Some significant points which are effective in deciding the most convenient scaling approach within the light of previous studies [14-17] are listed below. Accordingly, the scaling should be independent from the structure period and a period range should be covered rather than only a period, the number of earthquake record which is taken into consideration for deciding the earthquake demand of structure should be less as soon as possible and should include not only the far-field earthquake but also the near-field origin earthquakes and the earthquake distribution for the damage characteristic selected (the exceedance probability of spectrum or a spectral ordinate) should be protected for the relevant area (settlement area) and the scaling coefficient should not be very high (should be less than 4). Within the light of these explanations, the scaling of near-field motions selected were made at two stages. In the first stage, the earthquake record selected were brought into conformity with the target spectrum and in the second stage, the requirements of codes on dynamic analysis were met. The first stage was conducted in accordance with the methods which were defined by Huang [18] and used in the studies conducted by Constantinou et al. [19]. This scaling used in the aforementioned studies is known as the geo-mean (geometric average scaling). This method is an amplitude scaling method aiming minimizing the sum weight of square of the difference between the target spectral values at various periods and geometric average of horizontal component. In this method, the error difference $\varepsilon$ is defined as follows:

$$
\varepsilon=\sum_{i=1}^{n} b_{i}\left(\mathrm{a} y_{i}-y_{T i}\right)^{2}(2.1)
$$

$b_{i}$ in the equation (2.1) is the weight factor for the error square in the period of $T_{i}$. In the equation, $a$ is the scaling coefficient of relevant earthquake record, $y_{\mathrm{i}}$ is the 
geometric mean of spectral ordinates for the pairs in the period of $T_{i}, y_{T i}$ is the target spectral ordinate in the period of $T_{i}$ and $n$ is the target spectral value which is taken into consideration [18]. The scaling coefficient which gives the minimum value of error, $a$, is obtained in the way stated in Equation (2.3) based on the Equation (2.2) obtained by equaling the derivative of Equation (2.1) in accordance with $a$ to the zero.

$$
\begin{gathered}
\frac{\partial \varepsilon}{\partial a}=0 \rightarrow \sum_{i=1}^{n} b_{i} y_{i}\left(\text { a } y_{i}-y_{T i}\right)^{2}=0(2.2) \\
a=\left(\sum_{i=1}^{n} b_{i} y_{i} y_{T i}\right) /\left(\sum_{i=1}^{n} b_{i} y_{i}{ }^{2}\right)
\end{gathered}
$$

In Figure 10, the geometric mean of two horizontal components of acceleration spectrum of each earthquake record taken from the soil of which shear wave velocity of soil was $V_{s}=360-760 \mathrm{~m} / \mathrm{s}$ and the spectrum which was the average of these were shown. Similarly, the geometrical mean of two horizontal components of acceleration spectrum of ground motions recorded on the soil of which shear wave velocity of soil was $V_{s}=180-360 \mathrm{~m} / \mathrm{s}$ was shown in Figure 11. It was explained in the previous part of study that the convenient scaling shall cover a wide range of periods rather than a single period. In the Turkish Earthquake Code [11], the scaling is required to be made within the range of $0.2 \mathrm{~T}$ and $2.0 \mathrm{~T}$ ( $\mathrm{T}=$ First natural vibration period of building).

In this study, it was taken within the range of $0.2 \mathrm{~T}$ and $2.0 \mathrm{~T}$ which will cover both ranges. Therefore, the scaling was conducted in accordance with the five first natural vibration periods of buildings in the form of $\mathrm{T}_{\mathrm{i}}=0.2 \mathrm{~T}, 0.6 \mathrm{~T}, 1.1 \mathrm{~T}$, 1.6T, and 2.0T s. The coefficients' weight was decided by considering the spectrum which will yield the most convenient design for the spectrum scaled.

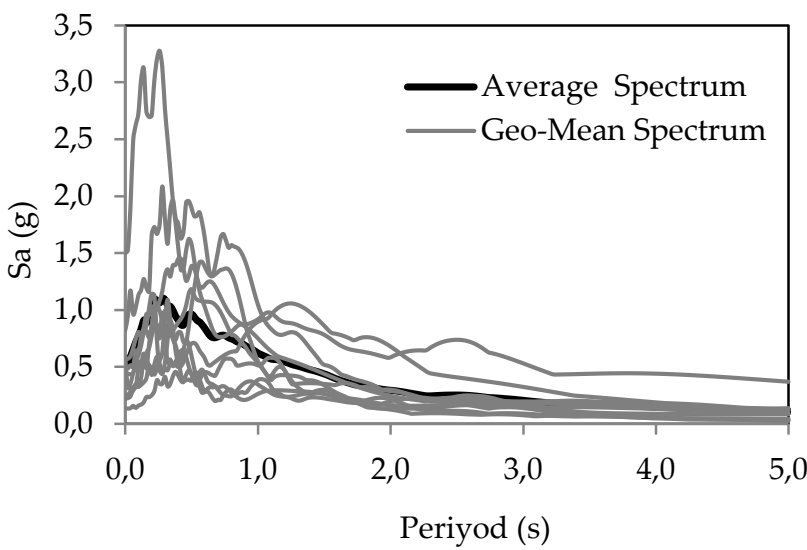

Figure 10. The geometric-mean and average spectrum of records taken from the soil group $C$ of which shear wave velocity was Vs=360-760 m/s.
In order to achieve the aim, the combination of weight factors is selected by selecting the most convenient combination through trying a serial. Consequently, the weighing factor for the relevant period was selected as 0.2 for each stage. These weighing factors were considered the same for all earthquake records [20].

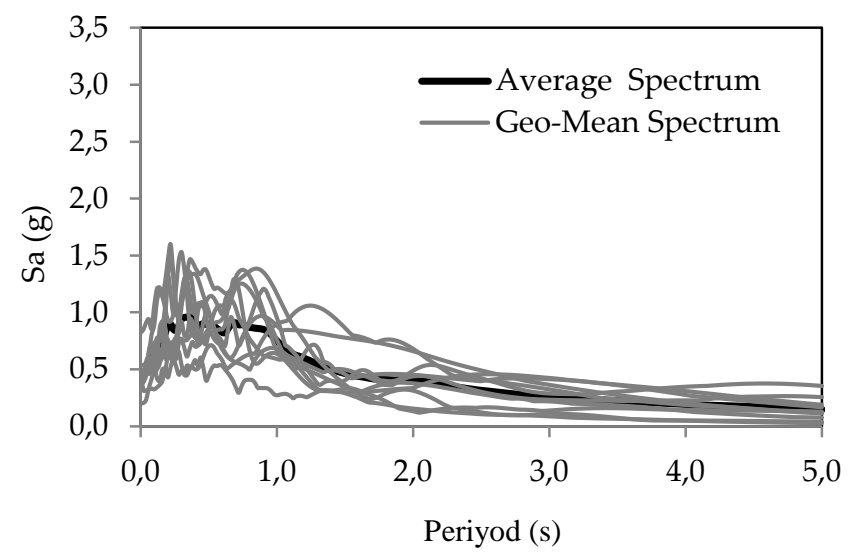

Figure 11. The geometric-mean and average spectrum of records taken from the soil group D of which shear wave velocity was $V s=180-360 \mathrm{~m} / \mathrm{s}$.

The scaling was made for the earthquake of which the probability of exceedance was $10 \%$ in 50 years which was defined in Turkish Earthquake Code. The scaling target design spectrum was selected as defined in the Turkish Earthquake Code for the records which were taken from both soils. Accordingly, the characteristic periods of target spectrums for the design earthquake considered were taken as $T_{A}=0.15 \mathrm{~s}$ and $T_{B}=0.40 \mathrm{~s}$ for soil group $\mathrm{C}\left(\mathrm{V}_{\mathrm{s}}=360-760\right.$ $\mathrm{m} / \mathrm{s}$ ) and $\mathrm{T}_{\mathrm{A}}=0.15 \mathrm{~s}$ and $\mathrm{T}_{\mathrm{B}}=0.60 \mathrm{~s}$ for soil group $\mathrm{D}$ $\left(\mathrm{V}_{\mathrm{s}}=180-360 \mathrm{~m} / \mathrm{s}\right)$. In the study, $\mathrm{A}_{0}=0.4$ (I. degree earthquake zone), $\mathrm{I}=1.0$ (office or dwelling structure) was accepted.

In Figure 12 and Figure 13, the average of square root (SRSS) of sum of squares of spectral coordinates of scaled ground motions which were obtained in accordance with the aforementioned calculation and the design spectrum considered are shown together for both soil classes. In the second stage of scaling (Figure 14 and Figure 15), the average SRSS values were brough into conformity with the target design spectrum defined in the spectrum within the range of $0.2 \mathrm{~T}$ and $2.0 \mathrm{~T}$. 
Celal Bayar University Journal of Science

Volume 13, Issue 3, p 695-705

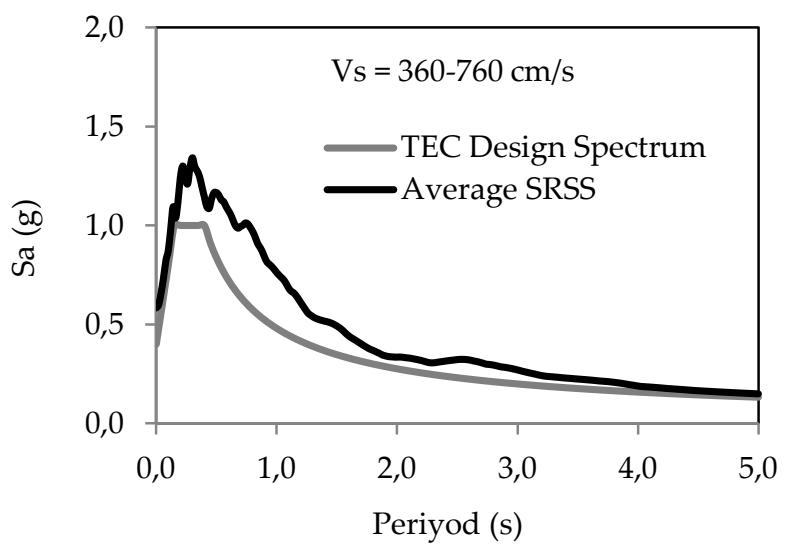

Figure 12. The average of square root of squares of records after first stage of scaling (SRSS) and design spectrum for $\mathrm{Vs}=360-760 \mathrm{~m} / \mathrm{s}$ (soil class $\mathrm{C}$ )

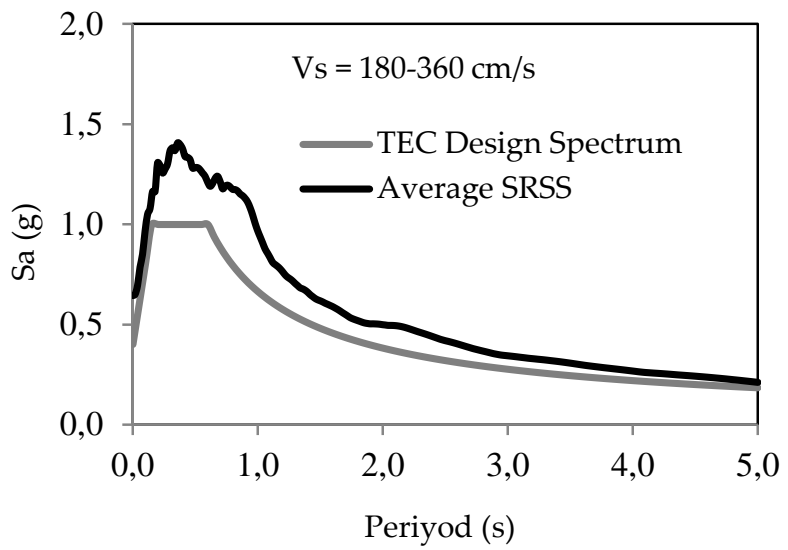

Figure 13. The average of square root of squares of records after first stage of scaling (SRSS) and design spectrum for $\mathrm{Vs}=180-360 \mathrm{~m} / \mathrm{s}$ (soil class D)

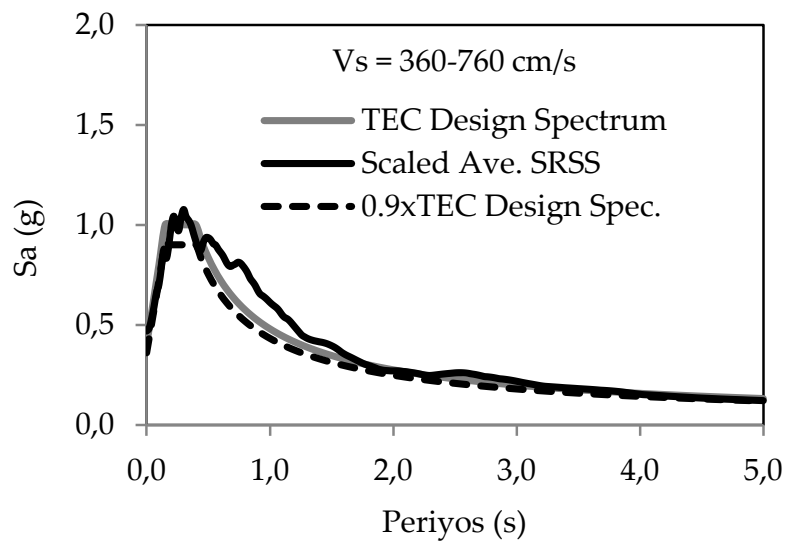

Figure 14. SRSS average, TEC design spectrums and 0.9xTEC Deisgn Spectrum of records after the second stage of scaling a) for $\mathrm{Vs}=360-760 \mathrm{~m} / \mathrm{s}$ (soil class $\mathrm{C}$ ).

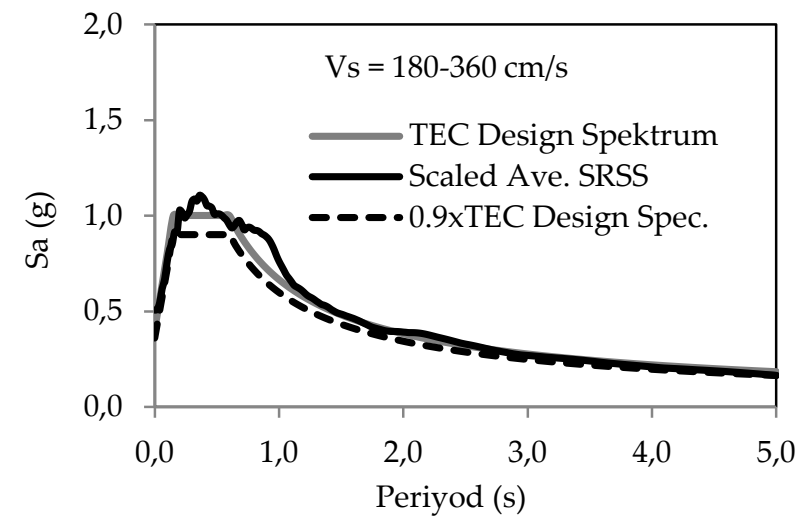

Figure 15. SRSS average, TEC design spectrums and 0.9xTEC Deisgn Spectrum of records after the second stage of scaling for Vs $=180-360 \mathrm{~m} / \mathrm{s}$ (soil class D)

In this stage, the scaling was made in the way of meeting the requirement of that the target response spectrums will not be lower than 0.9 times of design spectrum.

Table 5. The scaling coefficients obtained for the earthquakes selected.

\begin{tabular}{|c|c|c|c|}
\hline \multicolumn{2}{|c|}{$\begin{array}{c}\text { Vs }=360-760 \mathrm{~m} / \mathrm{s} \\
\text { (Soil Class C) }\end{array}$} & \multicolumn{2}{|c|}{$\begin{array}{c}\text { Vs }=180-360 \mathrm{~m} / \mathrm{s} \\
\text { (Soil Class D) }\end{array}$} \\
\hline $\begin{array}{l}\text { Earthquake } \\
\text { Record }\end{array}$ & $\begin{array}{c}\text { Scale } \\
\text { Factor }\end{array}$ & $\begin{array}{l}\text { Earthquake } \\
\text { Record }\end{array}$ & $\begin{array}{l}\text { Scale } \\
\text { Factor }\end{array}$ \\
\hline N-PKC & 0.74 & D-B & 0.59 \\
\hline CC-TCU68 & 0.62 & N-NWPC & 0.85 \\
\hline LP-SWVC & 1.15 & CC-CHY101 & 0.79 \\
\hline CC-CHY28 & 0.40 & CC-TCU101 & 1.50 \\
\hline LP-C & 0.64 & N-CCWLC & 0.61 \\
\hline IV-HPO & 1.12 & E-E & 0.71 \\
\hline CM-P & 0.70 & IV-ECD & 0.83 \\
\hline CM-CM & 0.36 & IV-ECA5 & 0.86 \\
\hline CC-TCU103 & 1.88 & IV-ECA7 & 0.72 \\
\hline LP-SAA & 0.83 & D-D & 0.66 \\
\hline
\end{tabular}

The final scaling coefficient obtained for each earthquake record was obtained by multiplying two scaling coefficients which had been obtained in two scaling stages. These final scaling coefficients obtained in conformity with the explanations are given in Table 5 for two soil statuses.

\subsection{The Analyses Conducted and The Data Obtained}

The unilinear time history analysis was conducted by using the earthquake records scaled on the analytical model of structure. In this analysis, it was accepted that the section damages accumulated in the junctures at the section end areas by taking the nonlinear material and geometry changes into consideration. In the analysis, the calculation was made in accordance with Newmark numercla integration method and critical structure damping ratio was 
accepted as 0.05 . At the end of analyses, the building effective modes, the displacements at the building nodal points, the rotation and internal forces were obtained. In the analyses, it was seen that the mass participation ratio fulfilled the requirements of codes.

In the analyses which were conducted with the records obtained from different soil classes, the variation graphics of Shear Force (V), Bending Moment (M) and Inter Storey Drift Ratio (IDR) values along with the story (N) were obtained for each record with the aim of seeing the change of structure response at every story. The average values belonging to that group obtained by averaging the curves created for each record are also shown.

In Table 6, maximum shear force, moment and inter storey drift ratio obtained from the analyses at which the earthquakes in soil class $C$ are shown. As seen from the table, the maximum shear force was found at the record of LP-SWVC as $\mathrm{V}_{\max }=119.1 \times 10^{3} \mathrm{kN}$ and the minimum shear force was found at the record of LP-C as $V_{\min }=52.0 \times 10^{3} \mathrm{kN}$. The average shear force in this set was $V_{\text {ave }}=75.4 \times 10^{3} \mathrm{kN}$. It was found in the set that $\mathrm{M}_{\max }=446.4 \times 10^{3} \mathrm{kNm}$ at $\mathrm{LP}$ SWVC record and $\mathrm{M}_{\min }=165.8 \times 10^{3} \mathrm{kNm}$ at LP-C record. The average bending moment in the set was $\mathrm{M}_{\mathrm{ave}}=275.9$ $\mathrm{x} 10^{3} \mathrm{kNm}$. The maximum inter storey drift ratio in the group was $I_{D R} R_{\max }=2.84 \times 10^{-3}$ at the record of LP-SWVC and $\mathrm{IDR}_{\min }=0.99 \times 10^{-3}$ at the record of LP-C. In the group, it was found as $\operatorname{IDR}_{\mathrm{ave}}=1.69 \times 10^{-3}$.

Table 6. The results obtained from the soil class C.

\begin{tabular}{|l|c|c|c|}
\hline $\begin{array}{l}\text { Earthquake } \\
\text { Record }\end{array}$ & $\begin{array}{c}\mathbf{V}_{\max } \\
(\mathbf{k N x 1 0})\end{array}$ & $\begin{array}{c}\mathbf{M}_{\mathbf{m a x}} \\
\mathbf{k k N m x 1 0}^{\mathbf{3}} \mathbf{)}\end{array}$ & $\begin{array}{c}\mathbf{I D R}_{\max } \\
\mathbf{( 1 0}^{-3} \mathbf{)}\end{array}$ \\
\hline $\begin{array}{l}\text { Northridge } \\
\text { (N-PKC) }\end{array}$ & 65.0 & 190.6 & 1.16 \\
\hline $\begin{array}{l}\text { Chi-Chi } \\
\text { (CC-TCU68) }\end{array}$ & 83.7 & 369.8 & 2.32 \\
\hline $\begin{array}{l}\text { Loma Prieta } \\
\text { (LP-SWVC) }\end{array}$ & 119.1 & 446.4 & 2.84 \\
\hline $\begin{array}{l}\text { Chi-Chi } \\
\text { (CC-CHY28) }\end{array}$ & 62.4 & 224.6 & 1.33 \\
\hline $\begin{array}{l}\text { Loma Prieta } \\
\text { (LP-C) }\end{array}$ & 52.0 & 165.8 & 0.99 \\
\hline $\begin{array}{l}\text { ImperialVall } \\
\text { (IV-HPO) }\end{array}$ & 77.7 & 308.7 & 1.89 \\
\hline $\begin{array}{l}\text { Cape Mendo } \\
\text { (CM-P) }\end{array}$ & 54.9 & 181.6 & 1.20 \\
\hline $\begin{array}{l}\text { Cape Mendo } \\
\text { (CM-CM) }\end{array}$ & 75.3 & 262.4 & 1.27 \\
\hline $\begin{array}{l}\text { Chi-Chi } \\
\text { (CC-TCU103) }\end{array}$ & 101.7 & 402.0 & 2.49 \\
\hline $\begin{array}{l}\text { Loma Prieta } \\
\text { (LP-SAA) }\end{array}$ & 62.3 & 207.5 & 1.40 \\
\hline Average & $\mathbf{7 5 . 4}$ & $\mathbf{2 7 5 . 9}$ & $\mathbf{1 . 6 9}$ \\
\hline
\end{tabular}

In Figure 16, the story - shear force, bending moment and inter storey drift ratio change curves obtained from soil class $\mathrm{C}$ are shown. The curves shown with the dotted lines in the figures indicates the results of each of seven earthquake in the group and the curve shown with the continuous line indicates the average of group.

The curve at the far right of floor level-shear force variation graphic given in Figure 16(a) indicates the results of LPSWVC record and the curve at the far left indicates the results of LP-C record while the curve at the far right of floor level-moment variation graphic given in Figure 16(b) indicates the results of LP-SWVC record and the curve at the far left indicates the results of LP-C record and the curve at the far right of floor level-interstory drift ratio (IDR) variation graphic given in Figure 16(c) indicates the results of LP-SWVC record and the curve at the far left indicates the results of LP-C record.

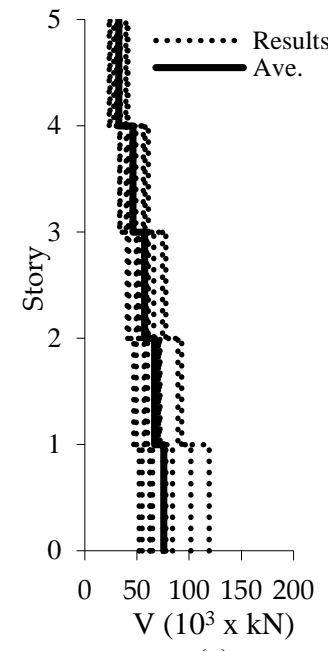

(a)

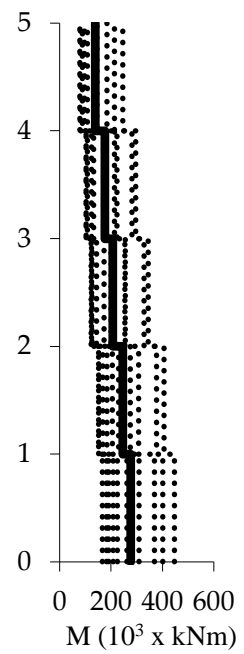

(b)

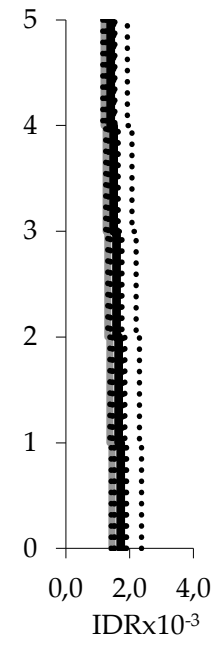

(c)
Figure 16. Soil class $C$ records group, Story - (a) Shear Force; (b) Moment; (c) Interstory Drift Ratio Diagram.

In Table 7, maximum shear force, moment and interstory drift ratio values obtained from the analyses at which the earthquakes in soil group D were used are shown. As seen from the table, the maximum shear force was at the record of N-NWPC as $\mathrm{V}_{\max }=151.3 \times 10^{3} \mathrm{kN}$ and the minimum shear force was at the record of N-CCWLC as $V_{\min }=65.1 \times 10^{3} \mathrm{kN}$. The average shear force in this set was $V_{\text {ave }}=100.4 \times 10^{3} \mathrm{kN}$. $\mathrm{M}_{\max }=541.9 \times 10^{3} \mathrm{kNm}$ was at the record of N-NWPC and $\mathrm{M}_{\min }=168.2 \times 10^{3} \mathrm{kNm}$ at the record of N-CCWLC in this set. The average bending moment in the set was $\mathrm{M}_{\mathrm{ave}}=312.1 \times 10^{3} \mathrm{kNm}$. The highest interstory drift ratio in the group was obtained in the record of N-NWPC as $\mathrm{IDR}_{\max }=2.64 \times 10^{-3}$ and in the record of NCCWLC as $I R_{\min }=1.04 \times 10^{-3}$. In the group, it was found as $\mathrm{IDR}_{\mathrm{ave}}=2.07 \times 10^{-3}$. 
Table 7. The results obtained from the soil class D

\begin{tabular}{|c|c|c|c|}
\hline $\begin{array}{l}\text { Earthquake } \\
\text { Record }\end{array}$ & $\begin{array}{c}V_{\max } \\
(\mathbf{k N x 1 0})\end{array}$ & 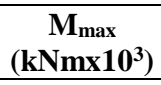 & $\begin{array}{c}\text { IDR }_{\max } \\
\left(10^{-3}\right)\end{array}$ \\
\hline $\begin{array}{l}\text { Düzce } \\
\text { (D-B) }\end{array}$ & 73.4 & 176.3 & 1.34 \\
\hline $\begin{array}{l}\text { Northridge } \\
\text { (N-NWPC) }\end{array}$ & 151.3 & 541.9 & 2.64 \\
\hline $\begin{array}{l}\text { Chi-Chi } \\
\text { (CC-CHY101) }\end{array}$ & 111.8 & 365.8 & 2.43 \\
\hline $\begin{array}{l}\text { Chi-Chi } \\
\text { (CC-TCU101) }\end{array}$ & 142.4 & 398.1 & 3.04 \\
\hline $\begin{array}{l}\text { Northridge } \\
\text { (N-CCWLC) }\end{array}$ & 65.1 & 168.2 & 1.04 \\
\hline $\begin{array}{l}\text { Erzincan } \\
\text { (E-E) }\end{array}$ & 84.7 & 291.2 & 2.03 \\
\hline $\begin{array}{l}\text { Imperial Val } \\
\text { (IV-ECD) }\end{array}$ & 101.8 & 290.0 & 1.97 \\
\hline $\begin{array}{l}\text { Imperial Val } \\
\text { (IV-ECA5) }\end{array}$ & 91.1 & 311.3 & 1.98 \\
\hline $\begin{array}{l}\text { Imperial Val } \\
\text { (IV-ECA7) }\end{array}$ & 99.9 & 261.5 & 2.32 \\
\hline $\begin{array}{l}\text { Düzce } \\
\text { (D-D) }\end{array}$ & 82.6 & 316.9 & 1.89 \\
\hline Average & 100.4 & 312.1 & 2.07 \\
\hline
\end{tabular}

In Figure 17, the story - shear force, bending moment and interstory drift ratio variation curves obtained from soil class D are shown.

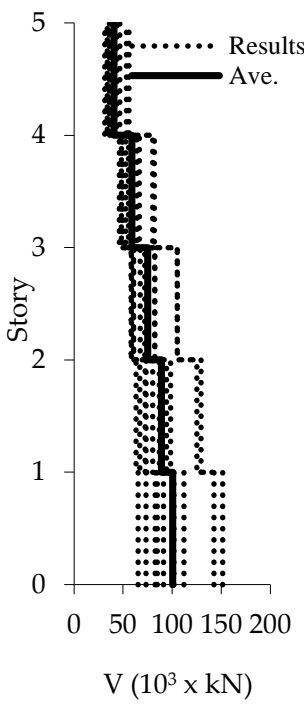

(a)

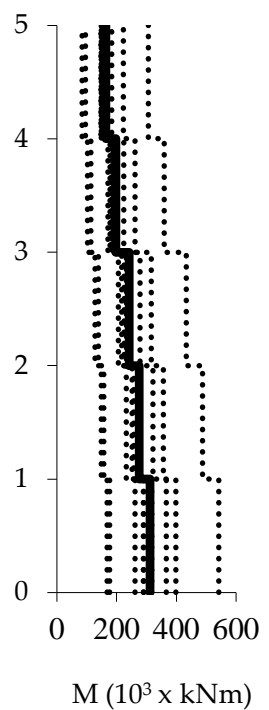

(b)

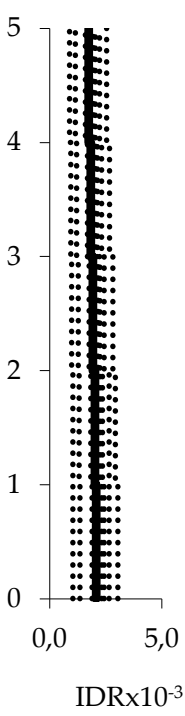

(c)
Figure 17. Soil class D records group, Story - (a) Shear Force; (b) Moment; (c) Interstory Drift Ratio Diagram.

The curve at the far right of floor level-shear force variation graphic given in Figure 17(a) indicates the results of NNWPC record and the curve at the far left indicates the results of N-CCWLC record while the curve at the far right of floor level-moment variation graphic given in Figure 17(b) indicates the results of N-NWPC record and the curve at the far left indicates the results of N-CCWLC record and the curve at the far right of floor level-interstory drift ratio (IDR) variation graphic given in Figure 17(c) indicates the results of N-NWPC record and the curve at the far left indicates the results of N-CCWLC record.

\section{Comparisons of Analysis Data}

In the codes concerning to the earthquake $[8,11]$, it is generally requested to reach the structure parameter to be controlled by averaging the earthquake record at the number of seven and above for the time history analysis. In this part, the average shear force, bending moment and interstory drift ratio, story curves obtained were each group were compared and discussed. In Figure 18, the curves concerning to this comparison are given. The dotted line in the story - shear force graphics given in Figure 18(a) indicates the group average of soil class $C$ and the continuous line indicates the group average of soil class D. In this graphic, the average maximum shear force value $\left(\mathrm{V}_{\max }\right)$ of soil class $\mathrm{C}$ was obtained at the first floor of structure as $75.4 \times 10^{3} \mathrm{kN}$ and minimum shear force value $\left(\mathrm{V}_{\min }\right)$ was obtained at the top floor of structure as $32.3 \times 10^{3}$ $\mathrm{kN}$. In the curve which is the average of soil group D, $\mathrm{V}_{\max }$ was $100.4 \times 10^{3} \mathrm{kN}$ at the fistr floor of structure and $V_{\min }$ was $40.6 \times 10^{3} \mathrm{kN}$ at the top floor of structure. In the story bending moment graphics given in Figure 18(b), the average maximum bending moment value of group $\mathrm{C}$ $\left(\mathrm{M}_{\max }\right)$ was $275.9 \times 10^{3} \mathrm{kNm}$ at the first floor of structure and minimum bending moment value $\left(\mathrm{M}_{\min }\right)$ was $137.8 \times 10^{3}$ $\mathrm{kNm}$ at the top floor of structure. In the curve which is the average of soil group D, $\mathrm{M}_{\max }$ was $312.1 \times 10^{3} \mathrm{kNm}$ at the fisrt floor of structure and $V_{\min }$ was $164.4 \times 10^{3} \mathrm{kNm}$ at the top floor of structure. In the story - bending moment graphics given in Figure 18(c), the average maximum bending moment value of group C (IDR $\max$ ) was $1.69 \times 10^{-3}$ at the first floor of structure and minimum interstory drift ratio value $\left(\mathrm{IDR}_{\min }\right)$ was $1.42 \times 10^{-3}$ at the top floor of structure.

In the curve which is the average of soil group $\mathrm{D}, \mathrm{IDR}_{\max }$ was $2.07 \times 10^{-3}$ at the first floor of structure and IDR $\min$ was $1.74 \times 10^{-3}$ at the top floor of structure.

It was seen in the graphics relevant to the comparison that the internal force and interstory drift ratio increased in case the record was taken from the soil class D but it could not be revealed that at which level this increase was. Therefore, the graphics concerning to the numeric comparison of both groups were created and the graphics created are shown in Figure 19. The curve at which the shear forces obtained from the soil class D were compared with the ones obtained from the soil class C. Accordingly, the shear force of structure at $2^{\text {nd }}$ floor obtained from soil 
group D was 33\% higher compared to the ones obtained from the soil class $\mathrm{C}$ and this value was the maximum difference between the shear forces.

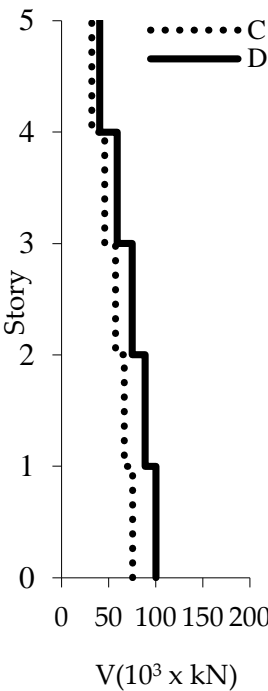

(a) (b)

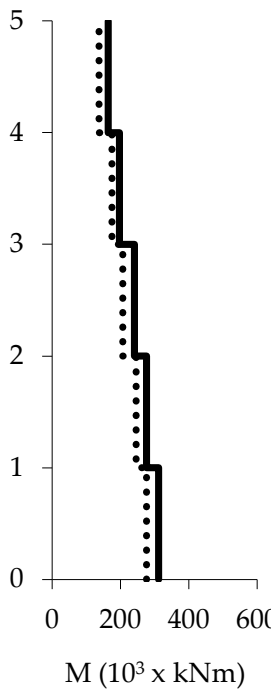

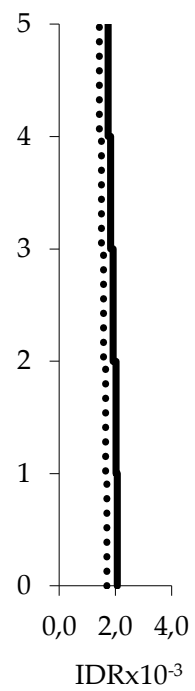

(c)
Figure 18. Comparison as per story of changes of (a) Shear Force, (b) Moment, (c) IDR obtained from soil class C records group and $\mathrm{D}$ records group.

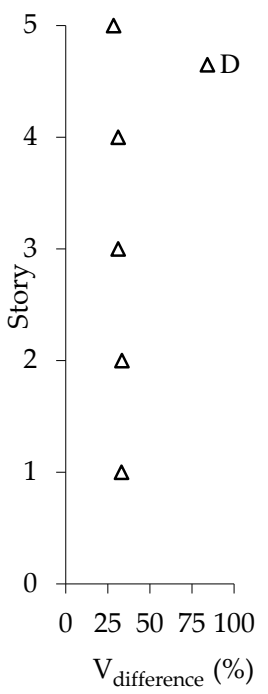

(a)

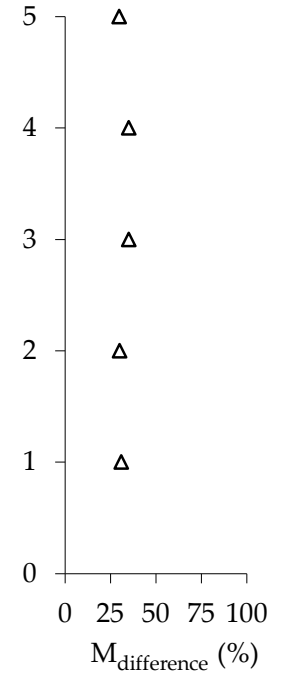

(b)

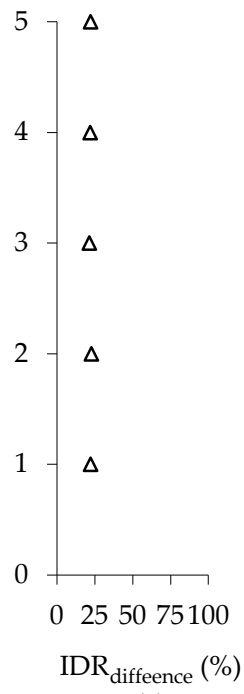

(c)
Figure 19. Proportionately comparison of changes of (a) Shear Force, (b) Moment, (c) Interstory Drift Ratio obtained from soil class $\mathrm{C}$ records group and $\mathrm{D}$ records group.

According to the bending moment curve given in Figure 19(b), the moment values obtained from the soil class were $35 \%$ higher at $3^{\text {rd }}$ floor of structure. According to the interstory drift ratio given in Figure 19(c), the difference between the values obtained from the soil class D was $23 \%$ higher at $2^{\text {nd }}$ floor of structure.

\section{Conclusions}

In this paper at which the investigation of effect of shear wave velocity of soils (soil class) to be used in the time history analysis on the mid-rise reinforced concrete frame structures was aimed, two different record groups taken from the soils of which shear wave velocity of soil was $V_{s}$ $=180-360 \mathrm{~m} / \mathrm{s}$ (soil class D) and shear wave velocity of soil was $\mathrm{V}_{\mathrm{s}}=360-760 \mathrm{~m} / \mathrm{s}$ (soil class $\mathrm{C}$ ). The records in these groups created were scaled at a period range in conformity with the design spectrum of which the probability of exceedance was $10 \%$ in 50 years as defined in Turkish Earthquake Code. The nonlinear time history analyses of a typical mid-rise reinforced concrete structure were conducted by using the earthquake records scaled. At the end of analyses, the shear force, bending moment at the structure floors and interstory drift ratio curves were created for each record. Following that, the average shear force, bending moment and inetrstorey drift ratio values of each group were obtained. The below-mentioned conclusions were reached when the analyses conducted within the scope of study and data were evaluated together.

- As the shear wave velocity of soil at which the earthquake record is taken decreases, the internal forces and displacements occurred at the structure increase.

- The shear forces obtained from the soils D of which shear wave velocity was $V_{s}=180-360 \mathrm{~m} / \mathrm{s}$ was $33 \%$ higher compared to the soil class $\mathrm{C}$ of which shear wave velocity was $\mathrm{V}_{\mathrm{s}}=360-760 \mathrm{~m} / \mathrm{s}$.

- The bending moments obtained from the soil class D with $V_{s}=180-360 \mathrm{~m} / \mathrm{s}$ were $35 \%$ higher compared to the soil class $C$ with $\mathrm{V}_{\mathrm{s}}=360-760 \mathrm{~m} / \mathrm{s}$.

- The interstory drift ratios obtained from soil class D with $\mathrm{V}_{\mathrm{s}}=180-360 \mathrm{~m} / \mathrm{s}$ were $23 \%$ higher compared to the ones obtained from the soil class $\mathrm{C}$ with $\mathrm{V}_{\mathrm{s}}=360-760$ $\mathrm{m} / \mathrm{s}$.

When all these results are evaluated together, it is observed that the structure is subjected to higher section forces as the shear wave velocity of soil decreases at which the earthquake record used in the time history analysis is taken within the frame of analyses made and higher displacements occurred at the structure. Therefore, the selection of earthquake records to be used in the nonlinear dynamic time history analysis in conformity with the field at which the structure will be constructed will be beneficial in terms of the earthquake resistant building design.

\section{References}

1. Celep, Z, Kumbasar, N, Deprem Mühendisliğine Giriş ve Depreme Dayanıklı Yapı Tasarımı, Beta Dağıtım, İstanbul, 2004. 
2. Fahjan, Y, Türkiye Deprem Yönetmeliği (DBYBHY, 2007) Tasarım İvme Spektrumuna Uygun Gerçek Deprem Kayıtlarının Seçilmesi ve Ölçeklenmesi, IMO Teknik Dergi, Temmuz 2008; Sayı 093, Cilt 19, 44234444.

3. Bommer, J.J, Acevedo, A.B, The Use of Real Earthquake Accelerograms as Input to Dynamic Analysis, Journal of Earthquake Engineering, 2004, 8(1), 43-92.

4. Jonathan, D.B, Adrian R.M, Characterization of forward-directivity ground motions in the near-fault region, Soil Dynamics and Earthquake Engineering, 2004, 24, 815-828.

5. Metin, A, Inelastic Deformation Demands on Moment-Resisting Frame Structures, PhD Thesis, Department of Civil Engineering, Middle East Technical University, 2006.

6. Mavroeidis, G.P, Modeling and Simulation of Near-Fault Strong Ground Motions for Earthquake Engineering Applications, PhD Thesis, Department of Civil, Structural and Environmental Engineering, State University of New York at Buffalo, 2004.

7. Ventura, C.E, Archila M, Bebamzadeh, A, and Liam W. D. F, Large coseismic displacements and tall buildings, The Structural Design of Tall and Special Buildings, 2011, 20, 85-99.

8. American Society of Civil Engineers, Minimum Design Loads for Buildings and Other Structures, Standard ASCE/SEI 7-05, Reston, VA. 2005.

9. Mander, J.B, Priestley, M.J.N, Park, R, Observed stress-strain behaviour confined concrete, Journal of Structural Engineering (ASCE), 1988, 114(8), 1827-1849.

10. Mander, J.B, Priestley, M.J.N, Park, R, Theoretical Stress-Strain Model for Confined Concrete, Journal of Structural Engineering (ASCE), 1988, 114, 1804-1826.

11. Türk Deprem Yönetmeliği (TDY), Bayındırlık ve İskan Bakanlığı,
Ankara, 2007.

12. XTRACT v3.0.8 Section Analysis Program (2013), Educational Version, Imbsen Software Systems, CA.

13. SAP2000, Structural Analysis Program, CSI Analysis Reference Manual for SAP2000, http://docs.csiamerica.com/manuals/etabs/, (accessed 08.07.2016)

14. Huang, Y.N, Whittaker, A.S, Constantinou, M.C, Seismic Demands on Secondary Systems in Conventional and Isolated Nuclear Power Plants, Proceedings Eighth US National Conference on Earthquake Engineering, Earthquake Engineering Research Institute, San Francisco, California, 2006.

15. Bommer, J.J, Acevedo, A.B, The Use of Real Earthquake Accelerograms as Input to Dynamic Analysis, Journal of Earthquake Engineering, 2004, 8(1), 43-92.

16. Baker, J.W, Cornell, C.A, A Vector-Valued Ground Motion Intensity MeasureConsisting of Spectral Acceleration and Epsilon, Earthquake Engineering and Structural Dynamics, 2005, 34(10), 1193-1217.

17. Hancock, J, Bommer, J.J, Stafford, P.J, Numbers of Scaled and Matched Accelerograms Required for Inelastic Dynamic Analyses, Earthquake Engineering and Structural Dynamics, 2008, 37, 1585-1607.

18. Huang Y.N, Performance Assessment of Conventional and Base-Isolated Nuclear Power Plants for Earthquake and Blast Loadings, PhD Thesis, Department of Civil, Structural and Environmental Engineering, State University of New York at Buffalo, 2008.

19. Constantinou, M.C, Whittaker, A.S, Fenz, D.M, Apostolakis, G, Seismic Isolation of Bridges, Department of Civil, Structural and Environmental Engineering, State University of New York at Buffalo, 2007.

20. Ozdemir, G, Constantinou, M.C, Evaluation of equivalent lateral force procedure in estimating seismic isolator displacements, Soil Dynamics and Earthquake Engineering, 2010, 30, 1036-1042. 